Environment and Experience 



\section{Environment and Experience}

Settlement Culture in Nineteenth-Century Oregon

\section{Peter G. Boag}

University of California Press

Berkeley - Los Angeles · Oxford 
University of California Press

Berkeley and Los Angeles, California

University of California Press, Ltd.

Oxford, England

(C) 1992 by

The Regents of the University of California

Library of Congress Cataloging-in-Publication Data

Boag, Peter G.

Environment and experience : settlement culture in nineteenth-century Oregon / Peter G. Boag.

p. $\mathrm{cm}$.

Includes bibliographical references and index.

ISBN 0-520-07719-9 (alk. paper)

1. Calapooia River Valley (Or.)-Historical geography. 2. Land settlement-Oregon-Calapooia River Valley-History-19th century.

3. Human geography-Oregon-Calapooia River Valley-History-19th century. I. Title.

F882.L7B62 1992

979.5'35-dc20

$92-12931$

CIP

Printed in the United States of America

987654321

The paper used in this publication meets the minimum requirements of American National Standard for Information Sciences-Permanence of Paper for Printed Library Materials, ANSI Z39.48-1984. 
In Memoriam

Elizabeth Ellen Oster Horand 
